\title{
A comparison of three trapping methods used to survey forest-dwelling Coleoptera
}

\author{
ESKo HYVÄRINEN, JARI KOUKI and PETRI MARTIKAINEN
}

Faculty of Forest Sciences, University of Joensuu, P.O. Box 111, FIN - 80101 Joensuu, Finland; e-mail: esko.hyvarinen@joensuu.fi

Keywords. Abundance distribution, beetles, biodiversity inventories, boreal forest, Coleoptera, interception traps, pitfall traps, sampling, species richness, window traps

\begin{abstract}
Sampling of insect communities is very challenging and for reliable interpretation of results the effects of different sampling protocols and data processing on the results need to be fully understood. We compared three different commonly used methods for sampling forest beetles, freely hanging flight-intercept (window) traps (FWT), flight-intercept traps attached to trunks (TWT) and pitfall traps placed in the ground (PFT), in Scots pine dominated boreal forests in eastern Finland. Using altogether 960 traps, forming 576 sub-samples, at 24 study sites, 59760 beetles belonging to 814 species were collected over a period of a month. All of the material was identified to species, with the exception of a few species pairs, to obtain representative data for analyses. Four partly overlapping groups were used in the analyses: (1) all, (2) saproxylic, (3) rare and (4) red-listed species. In terms of the number of species collected TWTs were the most effective for all species groups and the rarer species the species group composed of (groups 1-2-3-4) the larger were the differences between the trap types. In particular, the TWTs caught most red-listed species. However, when sample sizes were standardized FWTs and TWTs caught similar number of species of all species groups. PFTs caught fewer species of all species groups, whether the sample sizes were standardized or not. In boreal forests they seem to be unsuitable for sampling saproxylic, rare and red-listed species. However, the PFTs clearly sampled different parts of species assemblages than the window traps and can be considered as a supplementary method. The abundance distribution of saproxylic species was truncated lognormal in TWT and pooled material, whereas unclassified material failed to reveal lognormal distribution in all the trap types and pooled material. The results show that even in boreal forests sample sizes of at least thousands, preferably tens of thousands of individuals, collected by a high number of traps are needed for community level studies. Relevant ecological classification of material is also very important for reliable comparisons. Differences in the performance of trap types should be considered when designing a study, and in particular when evaluating the results.
\end{abstract}

\section{INTRODUCTION}

Insects numerically make up a major part of biodiversity (e.g. Erwin, 1982; May, 1988; Wilson, 1992) and make a fundamental contribution to ecological processes and ecosystem functioning. However, changes in the structure of insect communities caused by environmental changes are largely unknown due to problems with sampling and identification. Since insects utilize even the smallest of microhabitats (e.g. Komonen, 2003), they are likely to provide a very useful tool for observing changes in the environment. This, however, is possible only if the species can be identified and their habitat requirements are well known.

The use of Coleoptera in ecological studies, in particular community studies, has been rather uncommon. This is probably because it is very time consuming to identify them and obtain adequate data for analyses. Particularly in tropical forests the huge number of species, many un-described, makes the task even more difficult (Lawton et al., 1998). This forces ecologists to use morphospecies (Oliver \& Beattie, 1996) or higher taxa when analyzing samples. Moreover, the requirements of species are often poorly or unknown, which makes ecologically based classification of material impossible.

A high sampling effort is almost always required to obtain reliable information on insect communities (Longino et al., 2002) and in particular on rare and threat- ened species (McArdle, 1990; Muona, 1999; Novotny \& Basset, 2000; Martikainen \& Kouki, 2003). It has been suggested, that to obtain a representative sample of a local beetle community several collecting methods should be used simultaneously (Økland, 1996; Muona, 1999; Ozanne, 2005) and the result can be improved by placing the traps on different types of substrate, e.g. on different types of dead wood (Martikainen \& Kouki, 2003). However, in many cases it is not feasible to organize such large-scale inventories. To obtain representative samples the advantages and shortcomings of the available sampling methods need to be known in detail.

Several sampling methods have been developed for forest-dwelling insects (see, Southwood, 1978; Leather, 2005), such as interception (window) traps, malaise traps, pitfall traps, canopy fogging, sieving and direct searching. However, only a few of them are considered to be quantitative or semi-quantitative and thus suitable for numerical comparisons between areas or treatments. Flight-intercept traps and pitfall traps are fairly quantitative when properly used and can be used to collect a wide range of species, in particular Coleoptera, in different habitats. Flight-intercept traps and pitfall traps have been widely employed in many recent studies in boreal forests (e.g. Muona \& Rutanen, 1994; Siitonen, 1994; Spence \& Niemelä, 1994; Niemelä et al., 1996; Økland et al., 1996; 

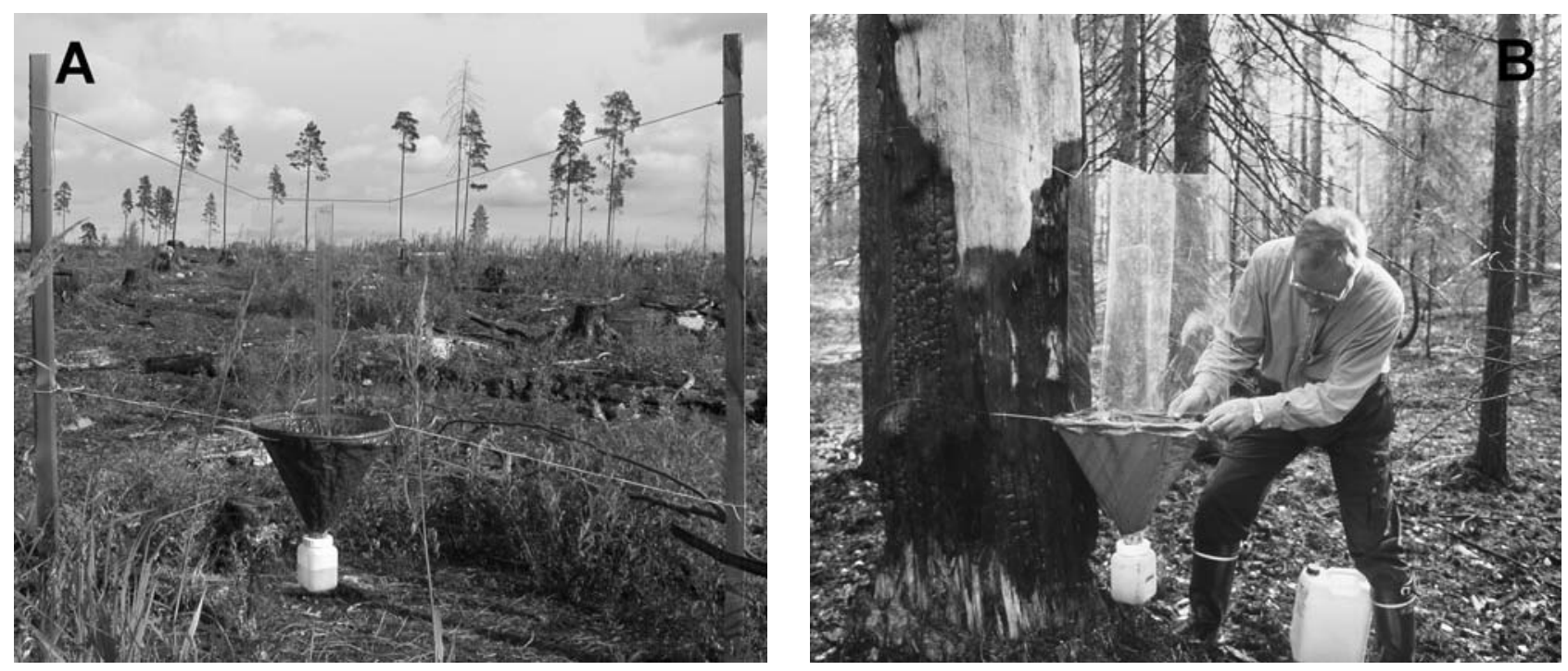

Fig. 1. A - freely hanging window trap and B - trunk window trap (with author J.K. installing the trap).

Martikainen, 2001; Koivula et al., 2002; Similä et al., 2002; Lindhe \& Lindelöw, 2004).

As there is great interest in the use of Coleoptera and other arthropods in biodiversity oriented studies, comparisons of different sampling methods are needed. Pitfall traps are the most widely used method in studies on Coleoptera, probably because they are very easy and cheap to use (Woodcock, 2005). Moreover, studies have usually concentrated on some easily sampled and relatively easily identified families, such as carabids. Since pitfall traps placed in the ground collect mainly litter-dwelling species, it may be anticipated that this trapping method may be unsuitable for obtaining representative data on forest-dwelling species in general and of one of the most species-rich group of forest species - saproxylics (deadwood dependent species) - in particular. Flight-intercept traps, on the other hand, collect only flying individuals, or if placed on tree trunks, individuals walking there, but do not catch most of the flightless litter-dwelling species.

To be able to choose the best method in relation to the objectives of a study it is important to have detailed information on the performance of different trap types and be aware of the shortcomings of the chosen method. It is important to understand the effects of the different sampling methods on the results when drawing conclusions. In this paper we compare three different sampling methods commonly used in studies of forest beetles: freely hanging flight-intercept (window) traps, flightintercept traps attached to trunks of trees, and pitfall traps.

\section{MATERIAL AND METHODS}

\section{Study area and experimental design}

Our data come from a large-scale field experiment set up to determine the effects of different forest management methods on biota. These effects are reported elsewhere (e.g. Hyvärinen et al., 2005); here the methodological aspects are considered. The experiment was carried out in state owned forests in eastern Finland (approx. $63^{\circ} 10^{\prime} \mathrm{N}, 30^{\circ} 40^{\prime} \mathrm{E}$ ), close to the border between the south and middle boreal vegetation zones (Ahti et al., 1968).
At the study area the mean annual temperature (1961-1990) is $+2.0^{\circ} \mathrm{C}$, and in July $+15.8^{\circ} \mathrm{C}$ and in January $-11.9^{\circ} \mathrm{C}$. The mean precipitation is $600 \mathrm{~mm}$ of which ca. $40 \%$ falls as snow. The study area is situated within a $20 \mathrm{~km} \times 30 \mathrm{~km}$ block, in which beetles were collected at 24 separate sites, representative of the pine-dominated forests in the region.

Prior to the start of the experiment the sites were mature 150year-old forests dominated by Scots pine (Pinus sylvestris L.), comprising on average $72 \%$ of the total volume of the growing stock, with some Norway spruce (Picea abies (L.) Karst.) $(22 \%)$, birch (Betula spp.) (5\%) and small numbers of other deciduous trees such as aspen (Populus tremula L.) and white alder [Alnus incana (L.)] (1\%). The ground-layer vegetation was dominated by Vaccinium myrtillus L. or V. vitis-idaea $\mathrm{L}$. depending on how moist the soil was within stands. The 24 study sites were logged according to experimental design during the winter 2000/01. There were three levels of green-tree retention: 0,10 and $50 \mathrm{~m}^{3}$ per hectare and un-harvested controls. In 10 and $50 \mathrm{~m}^{3}$ sites trees were mostly retained in small groups, but a few of them were also left as scattered single trees. Twelve of the 24 sites were burned 27.-28.6.2001. Each treatment was replicated three times. The standing dead trees were removed during cutting, in accordance with the experimental design, but fallen trunks were left intact. In the burning of the study sites most of the ground-layer vegetation was destroyed.

\section{Sampling and identification of beetles}

A total of 960 insect traps, forming 576 sub-samples, were used in this study. Ten freely hanging (FWT) (Fig. 1A) and ten trunk (TWT) flight-intercept (window) traps (Fig. 1B), and twenty pitfall traps (PFT) were set out at each study site. The window traps consisted of two perpendicular $40 \times 60 \mathrm{~cm}$ transparent plastic panes and a funnel (diameter of $40 \mathrm{~cm}$ ) leading down into a one-litre container. The pitfall traps consisted of two nested plastic mugs $(500 \mathrm{ml}$ and $300 \mathrm{ml})$, of which the inner mug had a diameter of $96 \mathrm{~mm}$ and depth of $121 \mathrm{~mm}$, and a transparent roof mounted $20-30 \mathrm{~mm}$ above ground. The $500 \mathrm{ml}$ mug facilitated the emptying of the traps. A solution of water and salt was placed in the traps to preserve the insects. A small amount of detergent was added to reduce the surface tension of the liquid. No attractants were used.

FWTs were suspended on strings between two poles or two trees and were located $20 \mathrm{~m}$ apart in a U-formation. TWTs were 
attached to standing dead trees or snags; five on pine, three on birch and two on spruce at each study site. The trees were chosen to be as similar as possible in size and stage of decay. The rim of the funnel of the trap was bent tightly against the tree. The spatial availability of dead trees determined the placing of TWTs. The FWTs and TWTs were hung (the rim of the funnel) $0.6-1.0 \mathrm{~m}$ above the ground. On the sites where 0 $\mathrm{m}^{3}$ of the trees were retained per hectare, TWTs were attached to the few remaining small snags, small diameter undergrowth trees or higher stumps. Thus, at $0 \mathrm{~m}^{3}$ sites TWTs were attached to lower quality substrates than at sites where more trees were retained, but still the substrates were considered to be attractive to at least some species. PFTs were set out in four groups of five traps with a minimum of $20 \mathrm{~m}$ between the groups. In a group, four of the traps were situated at the corners of a $2 \mathrm{~m} \times 2$ $\mathrm{m}$ square and the fifth in the middle. The samples from each group of five PFTs were pooled in the field when emptying the traps, thus giving four sub-samples per site. Samples from FWTs and TWTs were treated individually, giving $10+10$ subsamples per site. The trapping period was 10.6.-11.7.2002. Based on our unpublished data and long-term field experience most of the forest beetles are active at this time in Finland, as are the Carabidae (Niemelä et al., 1989).

The beetles were identified to species, except for two species of Staphylinidae, Amischa bifoveolata (Mannerheim) - A. nigrofusca (Stephens), and four species of Scolytidae Hylastes brunneus Erichson - H. cunicularius Erichson and Dryocoetes autographus (Ratzeburg) - D. hectographus Reitter. As it is very time consuming to identify large numbers of individuals of these very common species they were treated as species pairs. Stenus tarsalis Ljungh - S. bohemicus Machulka, Atheta crassicornis (Fabricius) - A. paracrassicornis Brundin, Scymnus frontalis (Fabricius) - S. mimulus Capra \& Fürsch were also treated as pairs since their females are almost impossible to identify to species. Twenty-eight specimens could not be identified to species, mostly due to deterioration, and were not included in the analysis. The nomenclature follows Silfverberg (2004).

\section{Data processing}

In the analyses four partly overlapping species groups were used: (1) all species, (2) saproxylic, (3) rare and (4) red-listed species. Facultatively saproxylic species were not classed as saproxylics. The species were classified on the basis of the relevant literature (Saalas, 1917, 1923; Palm, 1951, 1959; Koch, 1989-1992; Ehnström \& Axelsson, 2002) and our own experience. Species with at most 25 records in different locations in Finland during the years 1960-1990 were considered to be rare (Rassi, 1993). Red-listed species include threatened (IUCN categories CR, EN and VU) and near threatened species (NT) in Finland (Rassi et al., 2001).

Abundance distributions of species were examined by the method of Preston (1948), in which intervals (octaves) used for classification are $\log _{2}$-based $(0,1 ; 1,2 ; 2,4 ; 4,8 ; 8,16$; etc.). Species falling on a boundary between octaves were evenly divided between the octaves by adding 0.5 per species to each one. Due to the method used one half of the singletons are not shown in the figures. The normal-curves were fitted with Sigma Plot 8.0 using the three parameters option.

Individual based species accumulation curves were calculated for the pooled material for each of the trap types with EcoSim (Gotelli \& Entsminger, 2004). Sample based accumulation curves were drawn by first calculating the average number of species caught by all possible combinations for every number of traps (1-10) per trap type at each study site. Means were then calculated for the number of species caught at each study site (n $=24)$ for every number of traps $(1-10)$.
TABLE 1. Number of species and individuals in particular species groups sampled with different trap types. FWT $=$ freely hanging window trap; TWT $=$ trunk window trap; $\mathrm{PFT}=$ pitfall trap samples.

\begin{tabular}{lrrrr}
\hline Group & FWT & TWT & PFT & Total \\
\hline Number of species & & & & \\
$\quad$ All species & 542 & 615 & 294 & 814 \\
Saproxylic & 251 & 316 & 76 & 340 \\
Rare & 45 & 62 & 12 & 84 \\
$\quad$ Red-listed & 15 & 28 & 3 & 31 \\
Number of individuals & & & & \\
All species & 11708 & 23190 & 24862 & 59760 \\
Saproxylic & 6812 & 16125 & 6081 & 29018 \\
Rare & 347 & 792 & 25 & 1164 \\
Red-listed & 205 & 651 & 5 & 861 \\
\hline
\end{tabular}

In order to compare the effectiveness of different trap types a standard random sample of 400 individuals were taken from each of the trap types at each of the 24 sites. The randomization procedure was repeated 200 times for each sample. Eight freely hanging and four trunk window trap samples contained less than 400 individuals and were excluded from these analyses. Differences between the trap types in the number of species caught were tested using the Kruskall-Wallis test. Mann-Whitney U-test were applied as an a posteriori test with Bonferroni correction. The tests were performed using SPSS 11.5.

Non-metric multidimensional scaling (NMDS) was performed for the species assemblages using PC-ORD (McCune \& Mefford, 1997). Species recorded at only one site, or in one trap type at one site, were excluded and the data were $\log (x+1)$ transformed before performing NMDS. The Autopilot mode with "slow and thorough" settings was employed using the Sørensen (Bray-Curtis) distance measure. The similarities between the recorded assemblages (Bray-Curtis) were calculated with EstimateS 7.00 (Colwell, 2004).

\section{RESULTS}

\section{Differences in the number of species and individuals, and assemblages caught by the different types of trap}

Three different trapping methods, using 960 traps, caught a total of 59760 beetles belonging to 814 species (Table 1). Despite the differences between the study sites the effectiveness of the trap types were similar relative to each other when numbers of species were compared. On the burned sites, FWTs collected $84.1 \%$ and PFTs $47.6 \%$ of that caught by TWTs, and on unburned sites $84.0 \%$ and $47.8 \%$, respectively. There was more variation between different logging treatments. FWTs collected $73.5-94.6 \%$ and PFTs $43.4-54.0 \%$ of the number of species caught by TWTs, but the differences were not correlated with tree retention levels.

Species belonging to 65 families were caught of which 58 were caught by FWTs, 62 by TWTs and 40 by PFTs (Table 2). In general, the number of species recorded per family was higher in flight-intercept trap catches than PFTs. PFTs collected more species than either window trap only for three families: Carabidae, Byrrhidae and Coccinellidae, the difference being clear only for Carabidae. The two types of window trap performed more 
TABLE 2. Number of beetle species per family caught by the different trap types. FWT $=$ freely hanging window trap; TWT $=$ trunk window trap; PFT = pitfall trap samples.

\begin{tabular}{|c|c|c|c|c|c|c|c|}
\hline Family & FWT & TWT & PFT & Family & FWT & TWT & PFT \\
\hline Dytiscidae & 1 & 2 & 2 & Cucujidae & 1 & 1 & 1 \\
\hline Carabidae & 24 & 25 & 43 & Laemophloeidae & 4 & 5 & 1 \\
\hline Hydrophilidae & 5 & 4 & 1 & Cryptophagidae & 20 & 26 & 13 \\
\hline Histeridae & 3 & 10 & 2 & Erotylidae & 3 & 5 & 0 \\
\hline Ptiliidae & 11 & 9 & 1 & Byturidae & 1 & 0 & 0 \\
\hline Leiodidae & 19 & 15 & 9 & Cerylonidae & 4 & 4 & 1 \\
\hline Scydmaenidae & 5 & 7 & 3 & Endomychidae & 0 & 1 & 0 \\
\hline Silphidae & 1 & 2 & 2 & Coccinellidae & 5 & 5 & 8 \\
\hline Staphylinidae & 154 & 173 & 97 & Corylophidae & 3 & 4 & 0 \\
\hline Lucanidae & 0 & 1 & 1 & Latridiidae & 23 & 23 & 13 \\
\hline Geotrupidae & 1 & 1 & 1 & Mycetophagidae & 3 & 5 & 0 \\
\hline Scarabaeidae & 9 & 5 & 1 & Ciidae & 10 & 13 & 3 \\
\hline Clambidae & 2 & 1 & 2 & Tetratomidae & 0 & 1 & 0 \\
\hline Scirtidae & 5 & 5 & 2 & Melandryidae & 6 & 6 & 0 \\
\hline Buprestidae & 4 & 4 & 0 & Mordellidae & 4 & 4 & 2 \\
\hline Byrrhidae & 4 & 4 & 5 & Zopheridae & 2 & 3 & 0 \\
\hline Dryopidae & 1 & 0 & 0 & Tenebrionidae & 6 & 10 & 1 \\
\hline Throscidae & 1 & 1 & 0 & Oedemeridae & 1 & 2 & 0 \\
\hline Elateridae & 26 & 26 & 14 & Boridae & 0 & 1 & 0 \\
\hline Lycidae & 2 & 3 & 2 & Pythidae & 0 & 1 & 0 \\
\hline Lampyridae & 1 & 1 & 0 & Pyrochroidae & 1 & 1 & 0 \\
\hline Cantharidae & 17 & 13 & 4 & Salpingidae & 3 & 4 & 1 \\
\hline Dermestidae & 2 & 5 & 0 & Anthicidae & 0 & 1 & 1 \\
\hline Bostrichidae & 1 & 2 & 0 & Aderidae & 2 & 2 & 0 \\
\hline Anobiidae & 12 & 14 & 0 & Scraptiidae & 4 & 5 & 1 \\
\hline Lymexylidae & 1 & 1 & 0 & Cerambycidae & 22 & 25 & 6 \\
\hline Trogossitidae & 2 & 3 & 0 & Chrysomelidae & 9 & 13 & 7 \\
\hline Cleridae & 2 & 2 & 1 & Nemonychidae & 1 & 0 & 0 \\
\hline Melyridae & 3 & 3 & 1 & Anthribidae & 1 & 4 & 1 \\
\hline Sphindidae & 2 & 2 & 2 & Attelabidae & 3 & 1 & 1 \\
\hline Nitidulidae & 18 & 25 & 8 & Apionidae & 0 & 2 & 0 \\
\hline Monotomidae & 7 & 8 & 4 & Curculionidae & 52 & 58 & 25 \\
\hline Silvanidae & 2 & 2 & 0 & & & & \\
\hline
\end{tabular}

or less equally, when numbers of species per family were analysed. However, for some families there were clear differences. TWTs were more effective, e.g., in catching Histeridae, Staphylinidae, Nitidulidae, Cryptophagidae and Tenebrionidae. FWTs performed better, e.g., in catching Leiodidae, Scarabaeidae and Cantharidae. Of the species caught, $19.2 \%$ were caught exclusively by FWTs, $26.2 \%$ by TWTs and $24.5 \%$ by PFTs. According to the NMDS-ordination, there were practically no differences between the samples collected by TWTs and FWTs, while PFTs caught a clearly different assemblage of species (Fig. 2).

TWTs contributed most and PFTs the least to the number of species (Table 1). Although PFTs caught the largest number of individuals, the total number of species caught by the PFTs was only about half of that caught by other types of trap. Of the species caught by FWTs, 46.3\%, TWTs $51.4 \%$ and PFTs $25.9 \%$ were saproxylics.

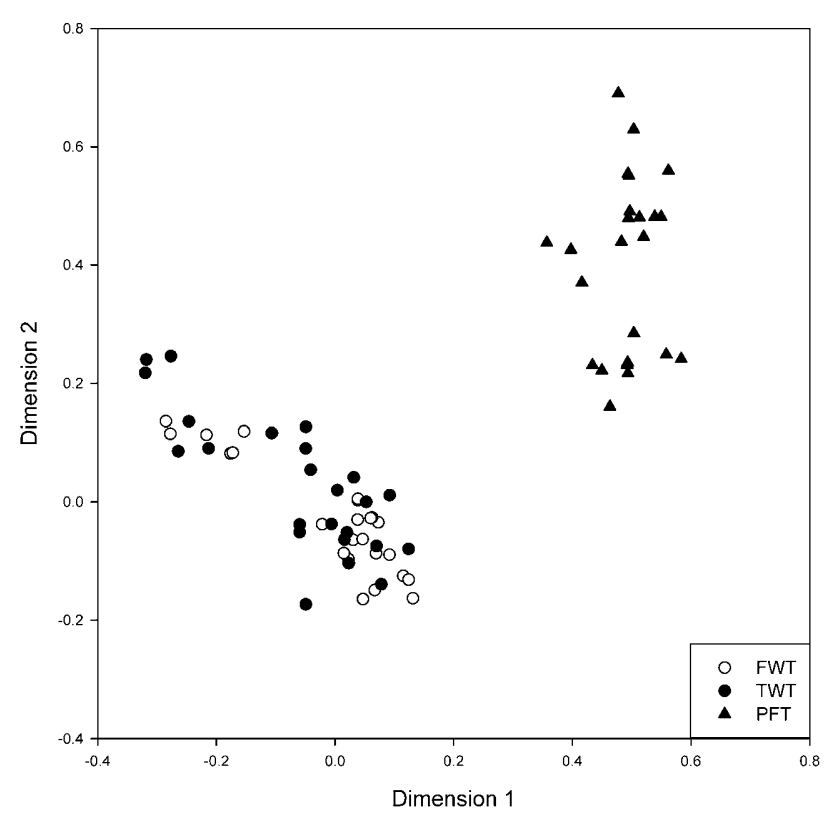

Fig. 2. The first two dimensions of a three-dimensional NMDS ordination of the three trap types (592 species, 24 sites). Final stress for ordination is 26.034. FWT - freely hanging window trap, TWT - trunk window trap and PFT - pitfall trap samples.

The proportion of red-listed species caught by the different types of trap differed. Of the species caught by FWTs $2.8 \%$, TWTs $4.6 \%$ and PFTs $1.0 \%$ were red-listed.

Based on standardized samples of 400 individuals per study site the two types of window trap did not differ in the number of species recorded in the four species groups, while the pitfall traps caught the lowest number of species in every group (Fig. 3A). However, when nonstandardized samples were investigated, there were differences in the catches of the three types of trap for all species groups, particularly the rarer species the studied species group composed of the more the three types of trap differed (Fig. 3B). In particular, in catching red-listed species TWTs were superior to the other types of trap (Table 3).

The Bray-Curtis similarity index for the FWT subsamples at each study site was on average $0.32(S D=$ $0.07)$ and TWT sub-samples $0.30(S D=0.08)$. There was no difference between the two types of window traps (Paired samples T-test: $t=1.393, d f=23, p=0.177$ ). The standard deviations also did not differ (Paired samples T-test: $t=-1.309, d f=23, p=0.204)$. The similarity of pitfall sub-samples was higher, on average $0.57(S D=$ $0.11)$.

\section{Accumulation of species in the different types of trap}

Individual based species accumulation curves revealed clear differences between the trap types (Fig. 4). Accumulation of species in the PFTs decelerated sooner than in both types of window trap, in which the accumulation of species continued at higher rate for much longer. In addition, in the FWTs the accumulation of species seemed to remain at a higher rate than in the TWTs. 
TABLE 3. Number of individuals of red-listed species caught by the different trap types. Red-list categories are: $\mathrm{EN}=$ endangered; $\mathrm{VU}=$ vulnerable; $\mathrm{NT}=$ near threatened; FWT $=$ freely hanging window trap; TWT $=$ trunk window trap; $\mathrm{PFT}=$ pitfall trap samples.

\begin{tabular}{|c|c|c|c|c|c|}
\hline Species & $\begin{array}{l}\text { Red-list } \\
\text { category }\end{array}$ & & & & Total \\
\hline Xyletinus tremulicola (Y. Kangas) & EN & - & 1 & - & 1 \\
\hline Trypophloeus asperatus (Gyllenhal) & $\mathrm{EN}$ & 1 & - & - & 1 \\
\hline avaljus brunneus (Gyllenhal) & VU & - & 3 & - & 3 \\
\hline Cerylon impressum Erichson & VU & - & 9 & - & 9 \\
\hline Clypastraea pusilla (Gyllenhal) & VU & 8 & 27 & - & 35 \\
\hline Corticeus longulus (Gyllenhal) & VU & - & 1 & - & 1 \\
\hline Boros schneideri (Panzer) & VU & - & 2 & - & 2 \\
\hline Acmaeops septentrionis (Thomson) & VU & 6 & 13 & - & 19 \\
\hline Acmaeops marginata (Fabricius) & VU & 1 & 2 & - & 3 \\
\hline Tropideres dorsalis (Thunberg) & VU & - & 1 & - & 1 \\
\hline Allandrus undulatus (Panzer) & VU & - & 1 & - & 1 \\
\hline Ptiliolum caledonicum (Sharp) & NT & 1 & 1 & - & 2 \\
\hline Agathidium pallidum (Gyllenhal) & NT & - & 1 & - & 1 \\
\hline Paranopleta inhabilis (Kraatz) & NT & 3 & 10 & - & 13 \\
\hline Cyphea latiuscula Sjöberg & NT & - & 1 & - & 1 \\
\hline Atrecus longiceps (Fauvel) & NT & - & - & 1 & 1 \\
\hline Melanophila acuminata (DeGeer) & $\mathrm{T}$ & 1 & 3 & - & 4 \\
\hline Lacon conspersus (Gyllenhal) & NT & 5 & 8 & - & 13 \\
\hline Lacon fasciatus (Linnaeus) & NT & 23 & 32 & - & 55 \\
\hline Ampedus suecicus Palm & NT & 3 & 8 & - & 11 \\
\hline Dermestes palmi Sjöberg & NT & - & 1 & - & 1 \\
\hline Stephanopachys substriatus (Paykull) & NT & - & 15 & - & 15 \\
\hline Stephanopachys linearis (Kugelann) & NT & 3 & 22 & - & 25 \\
\hline Ptinus sexpunctatus Panzer & NT & 1 & 3 & - & 4 \\
\hline Peltis grossa (Linnaeus) & NT & 3 & 3 & - & 6 \\
\hline Calitys scabra (Thunberg) & NT & - & 1 & - & 1 \\
\hline Atomaria elongatula Erichson & NT & - & - & 1 & 1 \\
\hline Corticaria fennica Johnson & NT & - & 1 & - & 1 \\
\hline Tomoxia bucephala Costa & NT & 10 & 26 & - & 36 \\
\hline Sphaeriestes stockmanni (Biström) & NT & 136 & 454 & 3 & 593 \\
\hline Xylotrechus rusticus (Linnaeus) & NT & - & 1 & - & 1 \\
\hline \multicolumn{2}{|l|}{ Total number of species } & 15 & 28 & 3 & 31 \\
\hline \multicolumn{2}{|l|}{ Total number of individuals } & 205 & 651 & & 861 \\
\hline
\end{tabular}

The number of traps used had a profound effect on the average number of species recorded per study site (Fig. $5)$. For all species groups, the accumulation of species in both types of window trap increased with increase in number of traps and still continued to increase when ten traps were used, while in PFTs the accumulation of species quickly decelerated. There were also clear differences in performance of the trap types when different species groups were investigated. For all species, seven TWTs caught more species than ten FWTs (see Fig. 5). For saproxylic and rare species the numbers were 5 to 10 , for red-listed species four TWTs caught larger numbers of species than ten FWTs. PFTs performed poorly in all species groups when compared to window traps. The total number of species caught by 20 PFTs was lower than that caught by three TWTs or four FWTs. For sampling
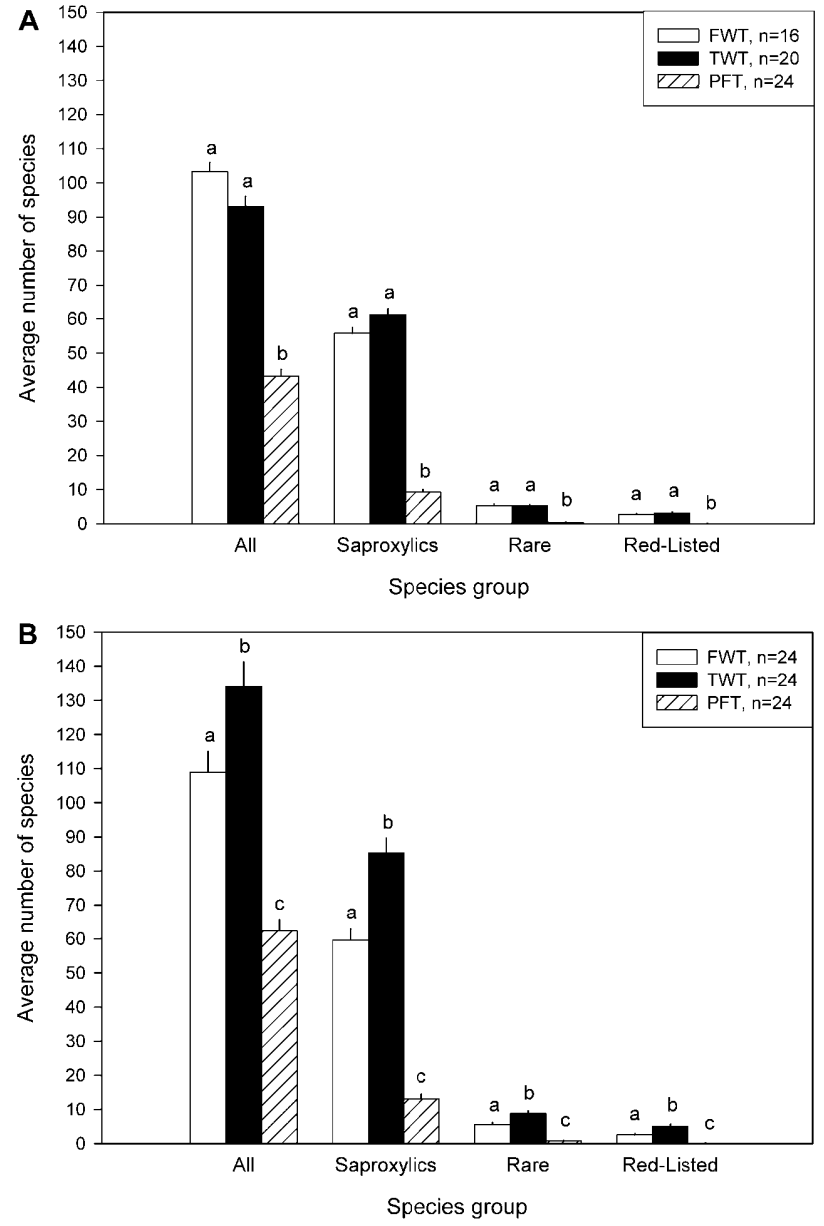

Fig. 3. Number of species caught per study site by the different trap types. Within a species group, bars with different letters above differ significantly from each other at the 5\% level (Mann-Whitney U-test with Bonferroni correction). A) Standardized samples of 400 individuals per study site, sites with less than 400 individuals are excluded. B) Non-standardized samples. Data presented are means and standard errors. FWT freely hanging window trap, TWT - trunk window trap and PFT - pitfall trap samples.

saproxylic and rare species one window trap of either type outperformed 20 PFTs. In particular, for sampling red-listed forest-dwelling beetles PFTs were very ineffective.

\section{Abundance distribution of species in different types of trap}

The abundance distribution of all the species in the different types of trap had the form of the right tail of a lognormal or logseries distribution (Fig. 6). The mode was in the first octave for every trap type and for the pooled material of all the trap types. For the pooled material, however, the normal curve seemed to approach a culmination point. For saproxylic species the pooled material from the three trap types and that from the TWT revealed a mode and had the form of a truncated lognormal distribution, whilst the form of that from the PFT was unclear. For the TWT material the mode was in the third and for the pooled material in the second octave, while for the 


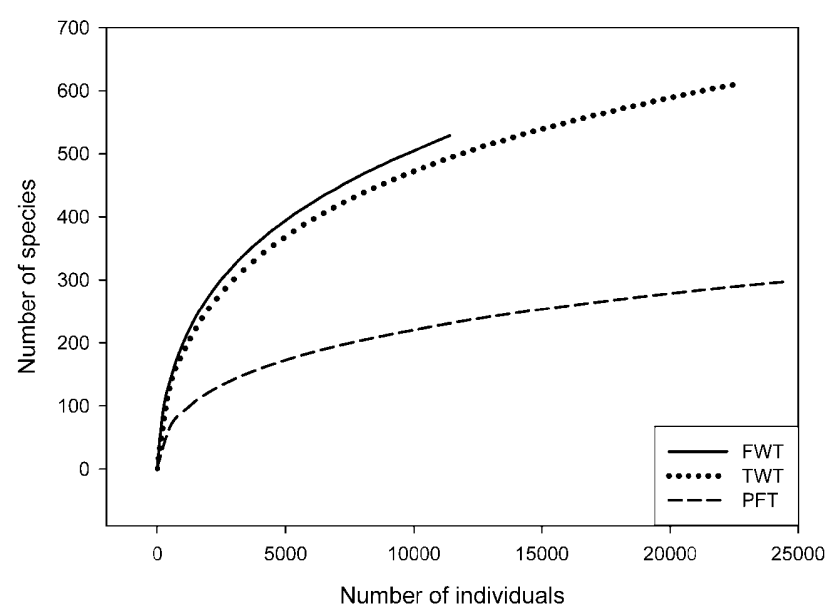

Fig. 4. Individual based species accumulation curves for the three trap types. FWT - freely hanging window trap, TWT trunk window trap and PFT - pitfall trap samples.

material from FWTs and PFTs the mode remained in the first octave. However, the normal curve of the FWT material seemed to approach a culmination point.

\section{DISCUSSION}

\section{Sampling effort and sample size}

According to Magurran (2004) sample sizes of a few hundred individuals are often adequate for many eco-
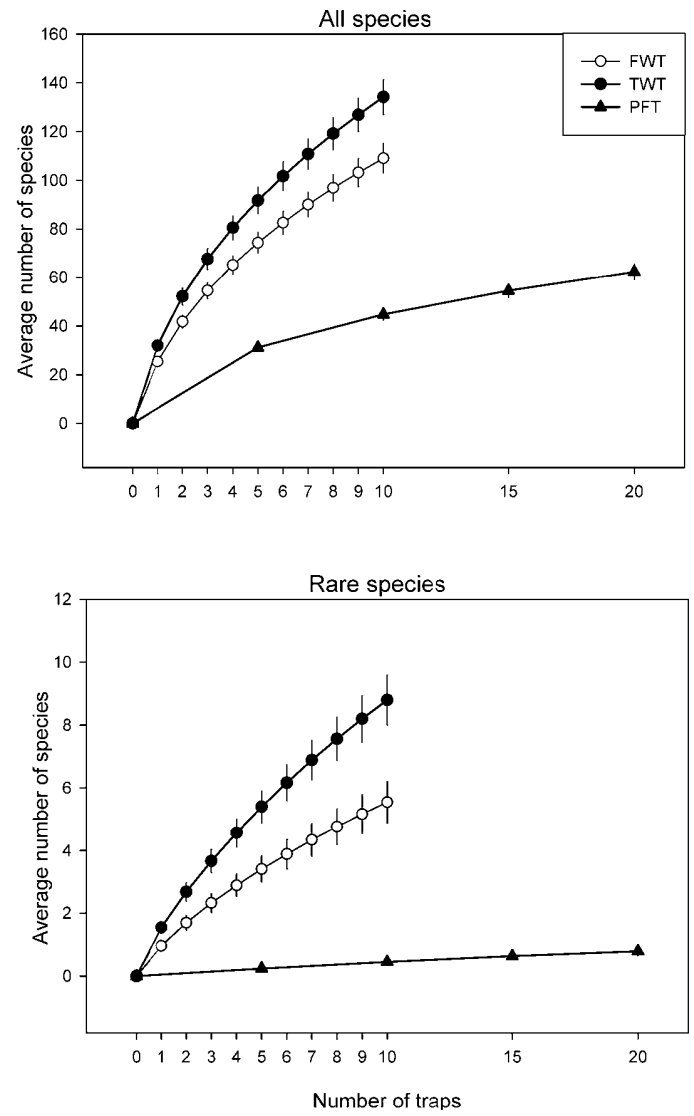

logical studies, although such data do not include rare species and are inappropriate for megadiverse assemblages such as tropical arthropods. Boreal forests are often considered to be relatively species poor, suggesting that representative sampling of their insect fauna, e.g. wood associated species, might be fairly easy. But this is clearly not the case, since boreal forests harbour a surprisingly high number of coleopteran species, easily reaching a level of one thousand species per stand (Hanski \& Hammond, 1995; Muona, 1999; Martikainen \& Kouki, 2003). Such a high species richness is rather amazing, because there are only a few tree species and, for example in Fennoscandia, the forests are mainly of pine, spruce and birch with some aspen and other deciduous trees. Our study clearly confirmed that even in boreal forests local beetle species richness can be so high that sample sizes of at least thousands of individuals, preferably tens of thousands, are needed to obtain a representative sample from a local community (see also, Muona, 1999; Martikainen $\&$ Kouki, 2003). The high beetle species richness is partly explained by the high number of saproxylic species utilizing the few tree species. For example, in Sweden there are about 380 species of beetle living on Scots pine, of which $6 \%$ live on live trees and the remaining 94\% in dead trees in different phases of decay (Ehnström, 1999). Since, based on these results, the sample sizes needed to determine such diverse insect assemblages are hard to obtain in relatively species poor boreal forests, in tropical
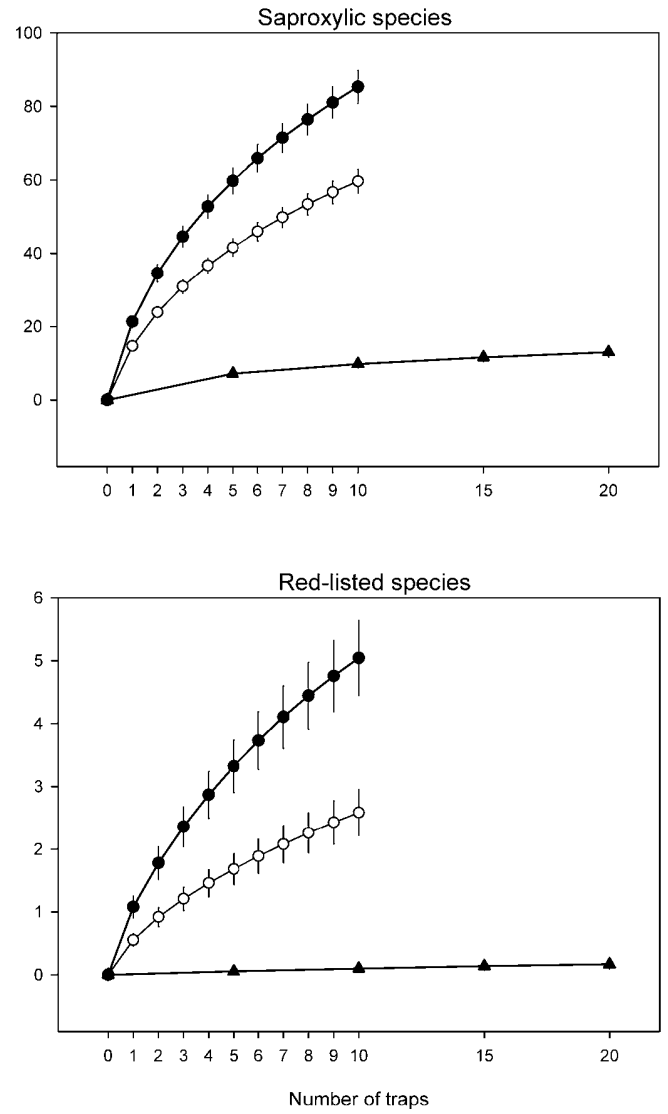

Fig. 5. Sample based species accumulation curves for the three trap types for all, saproxylic, rare and red-listed species. Note the variation in the scale on vertical axes. For calculation of the curves, see Material and methods. FWT - freely hanging window trap, TWT - trunk window trap and PFT - pitfall trap samples. 

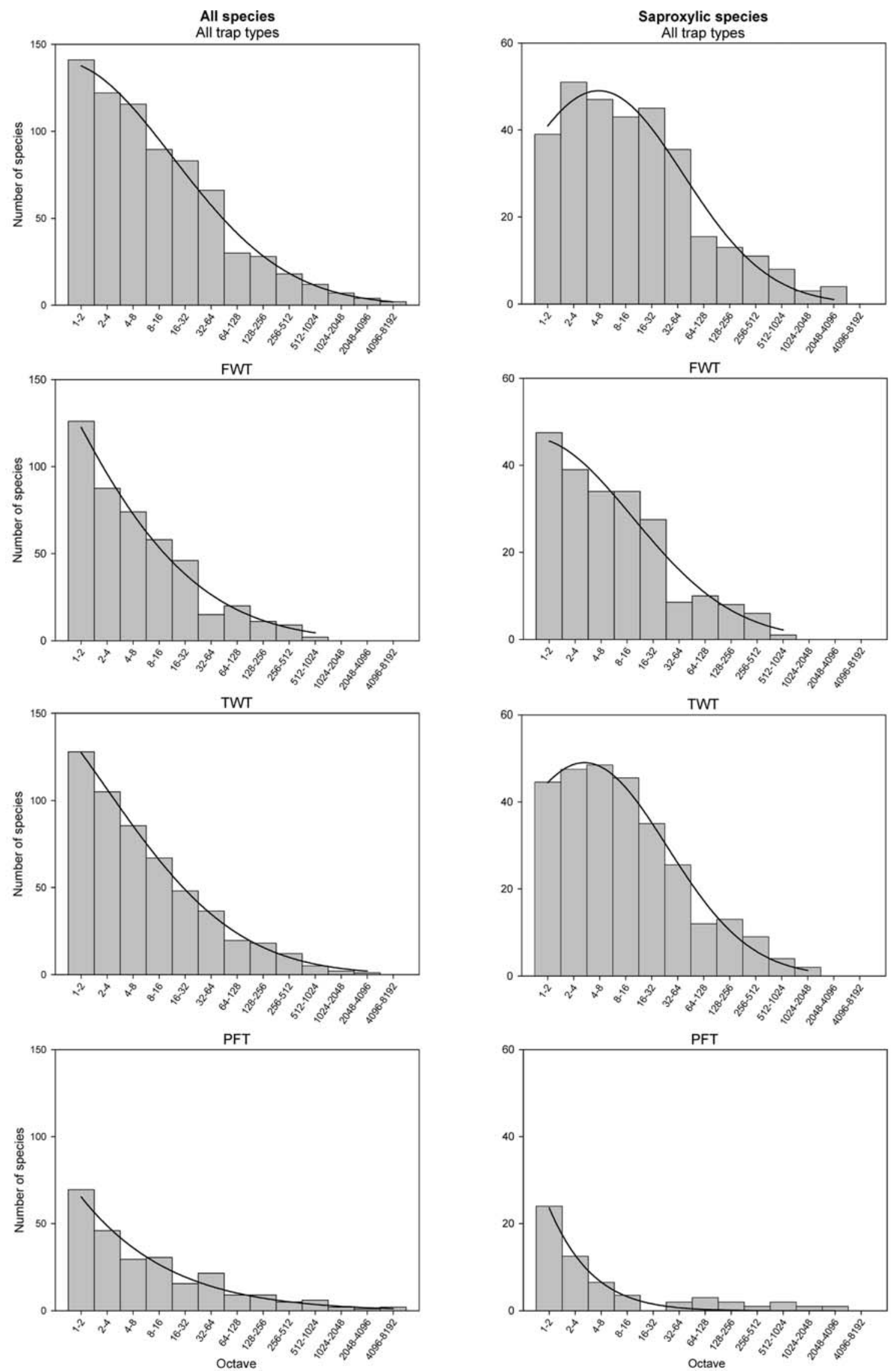

Fig. 6. Abundance distribution for all and saproxylic species caught by the three trap types and for pooled material from all the trap types. In addition, normal curves are fitted to $\log _{2}$ classified data (see Material and methods). Note the variation in the scale on vertical axes. FWT - freely hanging window trap, TWT - trunk window trap and PFT - pitfall trap samples. 
forests attaining a similar coverage of samples is probably beyond any available resources for megadiverse species groups such as Coleoptera (see also Lawton et al., 1998).

Sample based accumulation curves for window trap samples did not reach asymptotes even with ten traps per site. Ten window traps were sufficient to catch most of the common species occurring at a particular site, but not enough for detecting the rare species (see also, Martikainen \& Kaila, 2004). On the other hand, the pooled sample from the 24 sites was fairly representative - but not even close to complete - as the individual based accumulation curves indicated.

The level at which sampling should be done at every study site depends largely on the objectives and how the sampling is done. If sampling using ten window traps is to be continued throughout a season, the coverage of sitespecific samples can be expected to increase. Species accumulation curves for the pitfall samples indicated that this trapping method caught most of the species and thus these samples well represented the assemblages of litterdwelling beetles at the study sites. However, the trapping period of one month excluded most of the species that occur mainly in spring and autumn.

\section{Abundance distribution of species}

When a species abundance distribution follows a lognormal distribution, usually truncated, and reveals a clear mode it can be used as a basis for estimating the total species richness, i.e. adding species behind the veil line to observed species (Preston, 1948; Hayek \& Buzas, 1997). It can also be used to indicate sampling necessary to give an accurate representation of local species assemblages. The number of species inhabiting an area is of course temporally unstable due to various ecological processes. In tropical forests, where the number of species is still unknown, a reliable estimate of total species richness is of great interest. In many studies, however, the exact species richness of an area or difference between areas is of lesser interest, whereas changes in community structure and composition of assemblages can reveal much more about the underlying ecological processes. Even so, sufficient sampling of species assemblages is required. Examining the abundance distribution of species can be used to determine if the sampling is adequate. This could be informative, at least when diverse species groups such as Coleoptera are studied. However, there are indications that a log-normal distribution may not be generally applicable to all species groups (Hayek \& Buzas, 1997; Magurran, 2004) but appears to fit our data for saproxylic beetles in boreal forests.

The local species abundance distribution obtained using different sampling methods are affected by many factors. The most important are the effects of the different trapping methods on the species assemblages caught, i.e. methodological edge effects (Longino et al., 2002). The abundance distribution for all species recorded at the study area took the form of the right tail of a lognormal or logseries distribution with the mode in the first octave. When an ecologically well-defined group of forestdwelling species - saproxylics - was investigated the abundance distribution revealed a clear mode in the TWT and pooled material, which had a lognormal distribution, despite the fact, that the limited trapping period of one month obviously increased the number of temporal edge species occurring in low numbers. These differences in abundance distributions indicate that when trap material is studied, classification of species into ecologically relevant groups is important for revealing underlying ecological patterns. This, of course, requires good knowledge of the biology of the species. The number of so called "tourist" species can be high in trap material, especially in mosaic landscapes formed by different habitats. Thus comparisons of numbers of species, without relevant classification, can be misleading. However, classified material may still contain species confined to that habitat type, but actually occurring as "tourists" at a particular site.

The abundance distribution of species in PFTs did not reveal a mode other than in the first octave, although the species accumulation curves indicated sufficient sampling. Previously, the abundance distribution of carabids in pitfall samples from boreal forests was shown not to follow a lognormal distribution (Niemelä, 1993). In this study all the caught species were identified, but still the abundance distribution remained unclear. This was probably partly caused by an ecological classification unsuitable for pitfall material. In particular, PFTs in the ground are not suitable for studying saproxylic species, but still the proportion of saproxylics in the PFT-material was so high that it probably distorted the abundance distribution from showing the distribution of real litterdwelling species.

\section{Performance of trap types}

In this study there were clear differences in the performance of the three trap types. The results show that the three trapping methods collected more or less different parts of local species assemblages. According to the NMDS ordination there were no significant differences between the species assemblages caught by the two window trap types, but the method excluded singletons from the analyses. However, the more rare species in the species group studied, the larger were the differences between the three trap types. Based on the sample based species accumulation curves, TWT was the most effective trap type, clearly outperforming FWTs and PFTs for all species groups. In particular, of the total of 31 red-listed species 28 were caught by TWTs. In contrast, individualbased curves suggested higher accumulation rate of species in FWTs than TWTs. This discrepancy is caused by the method of calculating the curves. Sample based curves do not take into account the number of individuals, whereas for individual based curves the greater number of individuals caught by TWTs compared to FWTs greatly affects the shape of the curves (see also, Martikainen \& Kouki, 2003).

Differences in the performance of the trap types can partly be explained by the important role of dead wood as a substrate for beetles in boreal forests. Most families with species that are associated with dead wood were more species rich and abundant in TWTs than FWTs, 
resulting over twice the number of individuals and a higher number of saproxylic species caught by TWTs than FWTs. Thus, dead trees clearly had a baiting effect (Økland, 1996, Martikainen \& Kaila, 2004). The fact that TWTs also catch individuals moving on tree trunks, and not only flying individuals as FWTs do, increases the difference between the two types of window trap. Species in families, which were more abundant in FWTs than TWTs, such as Leiodidae, Scarabaeidae and Cantharidae, are largely dependent on substrates other than dead wood, such as dung and fungi, and are characterized by high flight activity. The higher effectiveness of PFTs than either window trap type in catching a few families, in particular Carabidae, was not surprising. However, the carabid species caught by PFTs were somewhat different from those caught by window traps, particularly by TWTs, since species living primarily on trees (e.g. Dromius spp.) were not caught by PFTs. The same applies to many other species of other families, as the NMDS ordination revealed. All the three trap types caught a fairly large proportion (19.2-26.2\%) of unique species, which shows that they complement each other.

Based on the number of individuals caught pitfall traps seem to be quite effective. However the high number of individuals caught consisted mainly of a few very abundant species, such as Corticaria rubripes Mannerheim, Zyras humeralis (Gravenhorst), Hylobius abietis (Linnaeus) and Otiorhynchus nodosus (Müller). These four species comprised more than half of the total number of individuals in PFTs. It seems, that species moving primarily on the ground, are fairly easily sampled by pitfall traps and five traps are sufficient to catch most of the species. However, in boreal forests where wood ants (species of the Formica rufa-group) have a great impact on the occurrence of other invertebrates (e.g. Niemelä et al., 1992), results are greatly affected by the location of traps. In ant-rich patches Zyras humeralis, with some other less abundant ant-associated species, can make up almost all of the beetle catch. In this case a higher number and more decentralized setting of the traps is recommended.

Similarity indices revealed no differences between the two window trap types. Similarity between PFT subsamples was higher than that of window trap samples, which was obviously affected by the pooling of material from five traps to form a sub-sample. However, it is also likely that in boreal forests the spatial homogeneity of the litter-dwelling fauna is higher than that caught by window traps. The fairly low variation in the moisture and microhabitats at ground level, typical of the forest type at the study sites, may also have resulted in the high similarity between the PFT sub-samples. TWTs have often been considered to be less quantitative than FWTs due to the variability in the baiting effect of trees and fungi on them (Økland, 1996; Martikainen, 2001; Komonen, 2003). The location of TWTs has an impact on the species caught and the results are highly dependent on the characteristics of the trap trees in study areas. Our study sites were fairly similar in forest type and representative of the dominant forest type in the area. Also the TWTs were placed as far as possible in similar position at the different study sites, taking into consideration tree species (pine, spruce and birch) and other tree characteristics, such as size and stage of decay. This probably resulted in the fairly high similarity among TWT catches, a result not necessarily always true.

Based on these results, PFTs can be used only as a supplementary method for studying forest-dwelling species, unless the focus of the study is clearly on litter-dwelling species. In boreal forests, the fauna associated with dead trees more accurately reflects the ecological properties of forests than litter-dwelling species, since dead trees are one of the most important factors affecting the biodiversity of boreal forests (e.g. Esseen et al., 1997).

The fauna associated with dead wood contains most of the threatened species in boreal forests of Fennoscandia (Anonymous, 2000) and a high number of other highly specialized species, whereas the litter-dwelling fauna is mainly composed of fairly generalist species able to thrive in many kinds of conditions and few true specialists. As the litter-dwelling fauna has little connection with dead wood, they probably cannot be used as a surrogate or indicator group reflecting changes in other groups of forest-dwelling species, such as saproxylics. Since the proportion of saproxylic species caught by TWTs was the highest $(51.4 \%)$, TWTs can be considered to be the most effective trapping method of the three used for sampling saproxylic beetle assemblages. Moreover, the proportion of red-listed species $(4.6 \%)$ was also highest in TWT material. The effectiveness of TWTs in sampling saproxylic beetles, although using a different trap design, has also been shown in tropical forests (Grove, 2000). As the FWT material also contained fairly high proportions of saproxylic $(46.3 \%)$ and red-listed $(2.8 \%)$ species and these traps have many benefits compared to TWTs, FWTs are a good method for sampling forest-dwelling species. When mainly interested in threatened species (e.g. in inventories), TWTs carefully positioned by an expert give by far the best results. However, when comparing areas, FWTs are probably more safe choice than TWTs.

\section{CONCLUSIONS}

The results of this study can be generalized only for habitats where trees of different ages and condition largely create and maintain the habitats for species, i.e. forests in the broad sense. In other habitats, also other methods are applicable, for example, pitfall traps can in some situations be very effective. When trap material is used for comparisons between areas, the method or methods should be chosen in accordance with the study objectives. The adequacy of the samples should always be estimated and the method for sampling justified before any conclusions concerning megadiverse species groups, such as Coleoptera, are made. Also, the classification of material into ecologically relevant groups is important. As observed in this study, different trapping methods and sample sizes can affect substantially the results and interpretation. The required sample sizes are very high even in boreal forests and high number of traps should be used. In 
particular if the aim of the survey is to detect rare and threatened species for conservation purposes, it is important to collect large samples using the appropriate traps. Generalizations based on small samples, collected by a few traps of one type, and of diverse species groups such as Coleoptera, are likely to be unreliable.

ACKNOWLEDGEMENTS. We would like to thank the Metsähallitus (former Finnish Forest and Park Service) (especially M. Ikonen, I. Heikkinen, K. Tuhkalainen, P. Leppänen and A. Tervonen) for providing and preparing the study sites for the experiment. We would also like to thank M. Karttunen and the staff of Mekrijärvi Research Station for sorting the beetle material for identification and H. Lappalainen, I. Rutanen and O. Heikkala for participating in the identification work. T. Clayhills is thanked for checking the identification of a Batrisodes hubenthali specimen. A. Komonen and three anonymous referees gave valuable comments on the manuscript. The study was funded by the Centre of Excellence Programme of the Academy of Finland (grant to J. Kouki, no. 64308), the Ministry of Agriculture and Forestry, the Ministry of Environment, the Finnish Forest Industries' Association, the Finnish Forest Research Institute and the Graduate School in Forest Sciences.

\section{REFERENCES}

Анті T., НӒмет-Анті L. \& Jalas J. 1968: Vegetation zones and their sections in Northwestern Europe. Ann. Bot. Fenn. 5: $169-211$.

ANONYMous 2000: Forest protection in Southern Finland and Ostrobothnia. The Finnish Environment 437. Ministry of the Environment, Helsinki, 284 pp. [in Finnish].

Colwell R.K. 2004: EstimateS. Statistical Estimation of Species Richness and Shared Species from Samples. University of Connecticut, Connecticut.

EhNSTRÖM B. 1999: Red listed beetles on Scots pine (Pinus sylvestris) in Sweden. Proceedings of the XXIV Nordic Congress of Entomology, pp. 55-61.

EHNSTRÖM B. \& AXELSSON R. 2002: Insektsgnag i bark och ved. [Galleries and Exit Holes of Insects in Bark and Wood.] ArtDatabanken, SLU, Uppsala, Sweden, 512 pp. [in Swedish].

ERwIN T.L. 1982: Tropical forests: their richness in Coleoptera and other arthropod species. Coleopts. Bull. 36: 74-75.

Esseen P.-A., Ehnström B., Ericson L. \& SJöBerg K. 1997: Boreal forests. Ecol. Bull. 46: 16-47.

Gotelli N.J. \& Entsminger G.L. 2004: EcoSim: Null Models Software for Ecology. Version 7. Acquired Intelligence Inc. \& Kesey-Bear, Jericho, VT 05465.

Grove S.J. 2000: Trunk window trapping: an effective technique for sampling tropical saproxylic beetles. Mem. Qld Mus. 46: 149-160.

HANSKI I. \& HAMmOND P. 1995: Biodiversity in boreal forests. Trends Ecol. Evol. 10: 5-6.

Hayek L.-A.C. \& BuzAs M.A. 1997: Surveying Natural Populations. Columbia University Press, New York, 448 pp.

Hyvärinen E., Kouki J., Martikainen P. \& Lappalainen H. 2005: Short-term effects of controlled burning and green-tree retention on beetle (Coleoptera) assemblages in managed boreal forests. For. Ecol. Manag. 212: 315-332.

Косн K. 1989-1992: Die Käfer Mitteleuropas. Ökologie. Bds. 1-3. Goecke \& Evers Verlag, Krefeld.

Koivula M., KuKKonen J. \& Niemelä J. 2002: Boreal carabidbeetle (Coleoptera, Carabidae) assemblages along the clear-cut originated succession gradient. Biodivers. Conserv. 11: $1269-1288$.
Komonen A. 2003: Hotspots of insect diversity in boreal forests. Conserv. Biol. 17: 976-981.

Lawton J.H., Bignell D.E., Bolton B., Bloemers G.F., Eggleton P., Hammond P.M., Hodda M., Holt R.D., Larsen T.B., Mawdsley N.A., Stork N.E., Srivastava D.S. \& Watt A.D. 1998: Biodiversity inventories, indicator taxa and effects of habitat modification in tropical forest. Nature 391: 72-76.

Leather S. (ed.) 2005: Insect Sampling in Forest Ecosystems. Blackwell, Oxford, $303 \mathrm{pp}$.

LindHe A. \& Lindelöw Å. 2004: Cut high stumps of spruce, birch, aspen and oak as breeding substrates for saproxylic beetles. For. Ecol. Manag. 203: 1-20.

Longino J.T., Coddington J. \& Colwell R.K. 2002: The ant fauna of a tropical rain forest: estimating species richness three different ways. Ecology 83: 689-702.

MagurRan A.E. 2004: Measuring Biological Diversity. Blackwell, Oxford, $256 \mathrm{pp}$.

MartiKainen P. 2001: Conservation of threatened saproxylic beetles: significance of retained aspen Populus tremula on clearcut areas. Ecol. Bull. 49: 205-218.

Martikainen P. \& Kaila L. 2004: Sampling saproxylic beetles: lessons from a 10-year monitoring study. Biol. Conserv. 120: $171-181$.

Martikainen P. \& Kouki J. 2003: Sampling the rarest: threatened beetles in boreal forest biodiversity inventories. Biodivers. Conserv. 12: 1815-1831.

MAY R.M. 1988: How many species are there on Earth? Science 241: 1441-1449.

McArdLE B.H. 1990: When are rare species not there? Oikos 57: 276-277.

McCune B. \& MefFord M.J. 1999: PC-ORD. Multivariate Analysis of Ecological Data, Version 4. MjM Software Design, Gleneden Beach, Oregon, USA.

Muona J. 1999: Trapping beetles in boreal coniferous forest how many species do we miss? Fennia 177: 11-16.

Muona J. \& Rutanen I. 1994: The short-term impact of fire on the beetle fauna in boreal coniferous forest. Ann. Zool. Fenn. 31: 109-121.

NIEMELÄ J. 1993: Mystery of the missing species - speciesabundance distribution of boreal ground-beetles. Ann. Zool. Fenn. 30: 169-172.

Niemelä J., Haila Y., Halme E., Pajunen T. \& Punttila P. 1989: The annual activity cycle of carabid beetles in the southern Finnish taiga. Ann. Zool. Fenn. 26: 35-41.

Niemelä J., Haila Y., Halme E., Pajunen T. \& Punttila P. 1992: Small-scale heterogeneity in the spatial-distribution of carabid beetles in the southern Finnish taiga. J. Biogeogr. 19: 173-181.

Niemelä J., Haila Y. \& Punttila P. 1996: The importance of small-scale heterogeneity in boreal forests: Variation in diversity in forest-floor invertebrates across the succession gradient. Ecography 19: 352-368.

NovotnÝ V. \& BASSET Y. 2000: Rare species in communities of tropical insect herbivores: pondering the mystery of singletons. Oikos 89: 564-572.

ØKLAND B. 1996: A comparison of three methods of trapping saproxylic beetles. Eur. J. Entomol. 93: 195-209.

ØKLand B., BaKke A., H̊̊gVar S. \& Kvamme T. 1996: What factors influence the diversity of saproxylic beetles? A multiscaled study from a spruce forest in southern Norway. Biodivers. Conserv. 5: 75-100.

Oliver I. \& Beattie A.J. 1996: Designing a cost-effective invertebrate survey: a test of methods for rapid assessment of biodiversity. Ecol. Appl. 6: 594-607. 
Ozanne C.M.P. 2005: Sampling methods for forest understory vegetation. In Leather S. (ed.): Insect Sampling in Forest Ecosystems. Blackwell, Oxford, pp. 58-76.

PaLm T. 1951: Die Holz- und Rinden-Käfer der nordschwedischen Laubbäume. Medd. St. Skogforskningsinst. 40(2): $1-242$.

Palm T. 1959: Die Holz- und Rinden-Käfer der süd- und mittelschwedischen Laubbäume. Opusc. Entomol. (Suppl. XVI), $374 \mathrm{pp}$.

PRESTON F.W. 1948: The commonness, and rarity of species Ecology 29: 254-283.

Rassi P. (ed.) 1993: Frequency Score of Coleoptera in Finland 1.1.1960-1.1.1990. Rep. No. 6. WWF Finland, Helsinki, 136 pp. [in Finnish, English abstr.].

Rassi P., Alanen A., Kanerva T. \& Mannerkoski I. (eds) 2001: The 2000 Red List of Finnish Species. Edita Plc, Helsinki, 432 pp. [in Finnish, English abstr.].

SaAlas U. 1917: Die Fichtenkäfer Finnlands. I. Ann. Acad. Sci. Fenn. (A) 8: 1-547.

SaAlas U. 1923: Die Fichtenkäfer Finnlands. II. Ann. Acad. Sci. Fenn. (A) 22 1-746.
Sirtonen J. 1994: Decaying wood and saproxylic Coleoptera in two old spruce forests - a comparison based on two sampling methods. Ann. Zool. Fenn. 31: 89-95.

Silfverberg H. 2004: Enumeratio nova Coleopterorum Fennoscandiae, Daniae et Baltiae. Sahlbergia 9: 1-111.

Similä M., Kouki J., Martikainen P. \& Uotila A. 2002: Conservation of beetles in boreal pine forests: the effects of forest age and naturalness on species assemblages. Biol. Conserv. 106: 19-27.

Southwood T.R.E. 1978: Ecological Methods. Chapman and Hall, London, $524 \mathrm{pp}$.

Spence J.R. \& Niemelä J. 1994: Sampling carabid assemblages with pitfall traps: the madness and the method. Can. Entomol. 126: 881-894.

WiLson E.O. 1992: The Diversity of Life. Belknap Press of Harvard University Press, Cambridge, MA, $424 \mathrm{pp}$.

Woodcock B.A. 2005: Pitfall trapping in ecological studies. In Leather S. (ed.): Insect Sampling in Forest Ecosystems. Blackwell, Oxford, pp. 37-57.

Received April 14, 2005; revised and accepted November 4, 2005 